\title{
MEB, Okul Pansiyonlarında Kalan Kız Öğrencilerde "Yoga Etkinliğinin Ders Dışı Eğitim Çalışmaları Kapsamında Uygulanabilirliğinin" İncelenmesi
}

\section{Analyze of the Female Students Who Stay Ministry of Education's School Pension in Terms of the "Feasibility of Yoga Activity on the Scope of Extracurricular Training"}

PInar GÜZEL ${ }^{*}$

Öz. Bu araştırmanın amacını, yoga etkinlikleri ile edinilebilecek kazanımların yanı sıra okuldaki hedeflerine katkı sağlayabilecekleri yolunda bilimsel tespitler yapmaktır. Bir diğer amaç ise ders dışı eğitim çalışmaları incelendiğinde yoga etkinlikleri ile ilgili elde edilebilecek kazanımların Milli Eğitim Bakanlığı (MEB) ders dışı eğitim (DDE) müfredatına alınması yönünde öneri sunmak oluşturmaktadır. Araştırma da nitel araştırma yöntemlerinden gözlem, görüşme ve doküman analizinden (günlüklerden) yararlanılmıştır. Araştırmanın çalışma grubunu; yoga etkinliklerine katılan 14-18 yaş grubunda kırk bir kız öğrenci oluşturmaktadır. Elde edilen veriler, "Nvivo 10 for Windows" programı aracılığıyla analiz edilmiştir. Çeşitleme yönteminin analizinde elde edilen veriler "farkındalığın oluşumu, fizyolojik kazanımlar, psikolojik kazanımlar, ders dışı eğitim önerisi olarak yoganın kazanımları" ana temaları altında sunulmuş ve alt temalara ulaşıımıştır. Verilerin analizı sonucunda; her birinde ortak olan iki (2) ana temaya ulaşılmıştır: ders dışı eğitim olarak yoganın kazanımları ve ders dışı eğitim önerisi olarak 'yoga'nın kazanımlarıdır. DDE çalışmaları kapsamında yapılan yoga uygulamalarının, katılımcıları zihinsel ve bedense olarak rahatlatarak üzerindeki stresi azalttığı tespit edilmiştir. Bu rahatlama bireyin yapacağı işe karşı duyduğu motivasyonu arttırmasının yanı sıra, ana odaklanmasını sağlayarak konsantrasyonuna da olumlu etki oluşturmaktadır. Birey kendine ayırdığı bu zaman içerisinde yaptığı yoga uygulamaları sonucunda bedensel ve ruhsal olarak gösterdiğ gelişimle sağlam bir özgüvene ve fiziksel sağlığa erişebileceği söylenebilir.

Anahtar Kelimeler: Yoga, ders dışı eğitim, okul pansiyonları, serbest zaman, kız öğrenciler.

Abstract. The main purpose of the study is to reach by yoga activities which thought to be implemented as extracurricular training of female students who stay school pension. With this study, it is aimed to make scientific determination about providing concentration and focusing; additionally to improve academic success, to make them healthier individuals, to gain self-confidence and self awareness and to make them feel happy and to offer a suggestion that providing acquisition which gained by yoga activities to take place on the Ministry of Education of Extracurricular training curriculum. It is benefited from observation, interviewing, and analyze of documents as diary on qualitative research methods in this study. 41 school going female students of 14-18 years are selected for the study. Datas are coded via Nvivo 10 for Windows programme. Common theme of coded data is classified by 2 experts. Data which are development of awareness, physiological and psychological acquisitions, implementation of extracurricular activity; in the analyze of triangulation method offers under the main theme and reach sub themes. It is given results concerning demographic data. It is reached two main common subjects for each as a result of gained data analysis by triangulation method. These are acquisition of yoga as extracurricular activities and offer of extracurricular activities. To sum up it is stated that yoga practices which is done in the frame of extracurricular training studies, reduce stress by relaxing applicants mentally and physically. This relaxation has positive impact on concentration by providing focus as well as increasing motivation to what people do. Thus, individuals who have self-awareness remove prejudice and start to think positively for the future. As a consequence of yoga activities applicants are improved mentally, physically. It makes individual to have self-confidence and physical health.

Keywords: Yoga, Extracurricular Training, Ministry of Education's School Pension, Leisure Time, Female Students.

\begin{abstract}
Toplumsal Mesaj. Bu araştırmanın amacı, Okul pansiyonlarında kalan kız öğrencilerin ders dışı eğitimde yoga etkinleri ile serbest zamanlarını değerlendirerek çeşitli kazanımlara ulaşmasına destek olmak ve bu kazanımların Milli Eğitim Bakanlığı ders dışı eğitim müfredatına alınması yönünde öneri sunmaktır. Sonuç olarak; yoga uygulamalarının öğrencilerde stresi azalttığı tespit edilmiştir. $\mathrm{Bu}$ rahatlama öğrencinin yapacağı işe karşı duyduğu motivasyonu arttırması ile bedensel ve ruhsal olarak gösterdiği gelişimle sağlam bir özgüvene ve fiziksel sağlığa erişebileceği söylenebilir.
\end{abstract}

Public Interest Statement. The aim of this research is to support the students staying at the school pensioners to reach various achievements by evaluating their leisure time with yoga activities in extracurricular education and also to propose these achievements into the curriculum of the Ministry of National Education. It has been found that yoga practices reduce stress in students. This relaxation can be said to increase the motivation for the work that the student is going to do, and to gain physical self-confidence and physical health through physical and mental development.

\footnotetext{
* Doç. Dr., Celal Bayar Üniversitesi, Spor Bilimleri Fakültesi, Rekreasyon Bölümü, pnrguzel@yahoo.com

** Zeytinburnu İhsan Mermerci Anadolu Lisesi, İstanbul, duygu.baysal36@gmail.com
} 


\section{GiRiş}

Dünya var olduğundan bu yana insanoğlu sürekli bir değişim ve gelişim içinde yaşamını sürdürmüştür. Bu değişim ve gelişim insanın hem yaradılış gereği merakıyla hem de üretme arzusuyla çevresinde meydana gelmiştir. Aynı zamanda varoluşundan bu yana bedeninde ve zihnindeki değişim ve gelişim de bilimsel araştırmalarla ortaya konmaktadır. Insanoğlu bazen yaşadığı dünyaya uyum sağlarken, bazen de yaşam kalitesini iyileştirebilmek adına dünyayı kendine uygun hale getirmek için muazzam buluşlarla modern dünyayı yaratmıştır. Bu dünya insana kolaylıklar sunarken, bazı olumsuzlukları da beraberinde getirmektedir. Dünya Sağlık Örgütü (WHO, 2015) kronik hastalıkların ortak risk faktörlerinden birisi olarak fiziksel inaktiviteyi (hareketsiz yaşam) göstermiştir ve dünya genelinde ölüme neden olan risk faktörleri sıralamasında dördüncü sırada yer alırken, ölümlerin \% 6'sının fiziksel inaktivite ile ilişkili nedenlere bağlı olduğunu bildirmektedir. Sağlık Bakanlığınca gerçekleştirilen "Türkiye Beslenme ve Sağlık Araştırması" sonuçlarına göre Türkiye'de bireylerin \%71.9'unun hareketsiz yaşadığı belirtilmektedir (Sağlık Bakanlığı [SB], 2014). Fiziksel gelişime katkıda bulunmak, eğitimin bütünlüğü içerisinde, yalnız beden eğitimi ve spor aracılığıyla olanaklıdır. Kaslar, kemikler ve eklemler, vücudun hareketini sağlarken; hareketler de bunların daha güçlü olmasına yardımcı olmaktadır. Dolayısıyla beden eğitimi ve spor etkinlikleri organik sistemlerin daha iyi gelişmesine yardımcı olmaktadır (Duman, 2003). Bugün geçmişe oranla insanların sahip oldukları serbest zaman dilimi giderek genişlemektedir. Avrupa standartlarına göre, 80 yıllık bir insan ömrünün \%32'lik zaman dilimi serbest zaman olarak şekillenirken, bu oran Türkiye'de kent insanında \%40 civarındadır. Bir yaşam süreci eğrisinde serbest zaman dilimi, iş zaman diliminden yaklaşık olarak dört kez daha büyüktür (Arslan, 2011). Tezcan (1993)'a göre serbest zamanı verimli bir şekilde geçirme isteğinin oluşması ve artması özellikle gençlerdeki olumsuz eğilimleri engelleyici bir etki yaratmaktadır. Gençlerin serbest zaman etkinliklerine yönelmelerinde ve etkinlik seçimlerinde aileleri, değer yargıları, bakış açıları ve farklı kültürlerden gelmeleri etkili olmaktadır. Toplumsal bütünleşmeyi sağlamada bir eğitim işlevine sahip olan serbest zaman eğitimi, edilgen kitleleri etken, olumlu ve yaratıcı kılmak üzere kullanılmaktadır. Serbest zaman çalışmalarının bireysel ve ulusal yönlerden kazandıracağı değerler yöre, bölge ve yurt sorunlarıyla ilgilenme ve bunların çözümlenmesinde görevler, roller yükleme gibi çok gerekli ve zorunlu sorumlulukları vardır (Can, 2010). Günümüz dünyasındaki teknolojik gelişmeler, toplumumuzdaki kültürel değişim ve insanın yaşama kalitesini arttırma arzusu geleneksel eğitimin yeterliliğinin sorgulanmasına neden olmuştur. Bu durumda serbest zaman eğitimini bireyin ihtiyaçlarına uygun şekilde değişmeye zorlamıştır. Serbest zaman eğitimi değişen eğitim anlayışı içinde önemli bir unsuru oluşturmakta, aynı zamanda örgün eğitim dışında da eğitimi doğrudan veya dolaylı olarak desteklemektedir. Eğitim sürecinin işlevliliğinde serbest zaman eğitiminin önemli bir yeri vardır (Ağaoğlu, 2002). Günümüzde teknolojik gelişmelere paralel olarak çalışma hayatı, ulaşım, serbest zaman aktiviteleri vb. gibi hareketli yaşantının giderek azalması sonucu, toplum sağlığı olumsuz yönde etkilenmektedir. Bu yaşam tarzını değiştirebilmek için, aile ve eğitimle küçük yaşlardan itibaren "herkes için spor" mantığı ile felsefesinin bireylerin yaşam biçimi haline getirilmesi ile ilgili farkındalık yaratılmalıdır.

Ertürk'e göre eğitim, bireyin davranışlarında kendi yaşantısı yoluyla ve kasıtlı olarak istendik değişiklik meydana getirme sürecidir (Demirhan, 2006). Eğitimin temel amaçlarından birisi ise, bireyin öğrendiklerini ders dışı eğitim çalışmaları ile hem yaşamlarına transfer etmelerini hem de öğrencilerin serbest zamanlarını etkili ve verimli şekilde geçirerek kötü alışkanlıklardan da uzak durmalarını sağlamaktır. Türkiye'de örgün eğitim genellikle bireyin akademik başarısını arttırmaya yönelik olmaktadır. Ancak akademik başarı bireyin mutlu olmasında tek başına yeterli değildir. Birey ilgi ve yeteneklerini tam olarak ortaya koyacak bir eğitim sistemi içinde olmazsa öğrenilen bilgiler günlük yaşamdan kopuklaşacaktır. Bu kopukluğu ortadan kaldırarak bireyin çok yönlü gelişimini sağlama noktasında devreye ders dışı etkinlikler girmektedir. Binbaşığlu (2000) ders dışı etkinlikleri, okulda veya okul dışında, eğitimin amaçlarına uygun olarak, öğrencilerin ilgi ve istekleri doğrultusunda, kişiliklerini geliştirmek için, okul yönetiminin bilgisi ve öğretmenin 
rehberliği altında yapılan, planlı, programlı ve düzenli çalışmalar olarak tanımlamıştır (Köse, 2004). Karaküçük ve Yetim (1999) ise ders dışı etkinlikleri, öğrencilerin zorunlu olarak katıldıkları ve önceden belirlenmiş müfredatlarını içeren derslerin dışında, tamamen kendi arzu ve tercihleri istikametinde katılııları her türlü spor, müzik, resim, tiyatro, edebiyat gibi faaliyetleri kapsaması şeklinde tanımlanmaktadır (Ekici ve ark, 2009). Pehlivan ve Selçuk (2005), okullarda ders yükünün fazlalığı, sınıfların kalabalık oluşu, ikili öğretim, materyal, araç-gereç, atölye, laboratuar, saha ve salonların eksikliği, bilgi birikiminin artması, ders programlarının yetersizliği ve bireysel farklılıkların belirginleşmesi gibi nedenlerden dolayı okulun, çocuğa istenen davranışları kazandırmada yetersiz kaldığını, bu nedenle de eğitim ve öğretimin, okulun ve ders saatlerinin dışını kapsamak zorunda olduğunu ileri sürmüşlerdir (Acar, 2012). Okul saatlerinden bağımsız olarak yapılan ders dışı etkinliklerin etkili ve verimli bir şekilde yapılabilmesi için okulun, ailenin ve çevrenin bu konuda işbirliği içinde olması gerekmektedir. Bu etkinliklerin planlanması, uygulanması ve değerlendirilmesi okulun ve öğretmenlerin görevidir. Gutowski'nin de belirttiği gibi, ders dışı program etkinlikleri okul merkezli bir sosyal yaşam organizasyonudur (Köse, 2004). Ders dışı etkinlikler bireyi toplumsal ve psikolojik açıdan geliştirip bilgi, beceri ve yeteneklerini daha da ileri taşıyarak zamanı daha verimli ve etkili kullanabilen gelecek nesiller yaratmayı amaçlaması açısından önemlidir. Ders dışı etkinliklerin olmadığı bir eğitim sistemi bütünleyici bir yaklaşım değildir. Öğrencilerin dersler işlenirken aldıkları veri ve malumatları kendi zihinlerinde yeniden yapılandırarak ve bunlara öznellik kazandırarak kendi bilgilerini üretme, ayrıca bu bilgileri yerinde ve zamanında kullanabilme kabiliyetlerini geliştirebilme açısından ders dışı etkinlikler oldukça önemlidir (Doydu, 2012). Dünyada ve Türkiye'de, öğrenim çağındaki gençlerin pek çoğunun eğitimlerini sürdürebilecek yeterli gelirlerinin bulunmaması ve içinde bulundukları değişik coğrafi yapılar ve sosyo-ekonomik koşullardan dolayı istedikleri halde eşit ve sağlıklı bir eğitim imkânı bulamamaktadırlar. Tüm eğitim sistemlerinde bu sorunu çözmek için yatıı öğrenim veren pansiyonlu okullar faaliyet göstermektedir (MEB-EAGDB, 2005). Millî Eğitim Bakanlığına Bağlı Okul Pansiyonları Yönetmeliğinde öğrencilerin okul sonrası yapacağı çalışmalara ilişkin sosyal faaliyet odalarından ve ilgi alanlarına uygun spor etkinlikleri yapabilecekleri salon ve odalardan bahsedilmekte ancak pek çok pansiyon binasının bu konuda yeterli olmadığı görülmektedir. Oysa yatılı öğrenim gören gençler akademik faaliyetlerin yanı sıra sosyal ve bedensel aktivitelere de intiyaç duymaktadırlar. Türkiye'deki pek çok okul pansiyonu gençlere arzu ettikleri hareketli yaşam imkanı sunmanın aksine hareketlerini kısıtlayacak ortamlar oluşturmaktadır. DDE çalışmaları planlı ve programlı bir şekilde öğrencilerin ihtiyaçlarına ne kadar hitap eder ve çeşitli olursa hem bireylerin gelişimine büyük katkı sağlayacağı, hem de eğitim-öğretimin başarısını arttıracağı görülmektedir. Özellikle okul pansiyonlarında kalan öğrencilerin daha iyi bir eğitim almak için geldikleri bu kurumlarda okul ve etüt saatleri dışında kısıtlı serbest zamanları kalmaktadır. Eğitim müfredatında öğrencilerin bu zamanını düzenlenecek ders dışı etkinliklerle, hareketsiz yaşantıdan kurtularak daha verimli hale getirmek ve yaşam kalitelerini arttırmak için seçenekler planlanmalıdır. Bu etkinliklere öneri olarak Yoga etkinliği verilebilir. Hint kültürünün önemli bir parçası olan yoga, son zamanlarda batı ülkelerinde artan sağlık sorunlarına etkin bir tedavi destek yöntemi olması dolayısıyla aktif bir şekilde uygulanır hale gelmiştir. Türkiye'de gittikçe yaygınlaşan yoganın tarihi çok eskilere dayanmaktadır. Yoga, "birlik ve bir olma" anlamına gelen sanskritçe bir sözcükten gelmektedir. Yoga aracılığıyla bilinç, ahenkli doğal bir şekilde genişlemektedir. Ayrıca insan bedeni fiziki anlamda da gelişim göstermektedir (Saraswati, 2001). Yoganın bir dalı olan medikal yoga ise besin, oksijen ve yaşam enerjisi gibi ihtiyaçları karşılanan hücreler rejenere olarak daimi yenilenme ve tamir yoluyla güzellik, sağlık ve biyolojik gençlik kazanırken bu intiyaçları yeterince karşılanamayan hücreler, karbondioksit ve toksinlerden temizlenemez. Bu da hücrelerde dejenerasyon yaratarak, şişmanlık, hastalık ve biyolojik yaşlanmaya neden olur (Akar, 2003). Yani kişi medikal yoga ile bedenini her yönüyle yoga yapabilir hale getirebilir. Yoganın kazanımları ile ilgili bu sonuçlar, özellikle toplumda sağlıklı yaşam kalitesini arttırmak misyonu ile hareket eden Türkiye Herkes iç̧in Spor Federasyonunu (HiS) da harekete geçirmiştir. His uluslararası alanda yoga ile yapılan gelişmeleri takip ederek Türkiye'de de fayda sağlayacak 
adımlar atmaktadır. "Yoga her yaşa, yoga ile yaşa" sloganı ile bünyesinde çalışmalarını sürdürmektedir (HIS, 2015).

Bu araştırmada bireylerin serbest zamanlarını uygulanan yoga etkinlikleri ile daha verimli kullanmaları sağlanarak bireyin yapılan işe odaklanma yönünü, konsantrasyonunu, okul başarılarını ve kendine olan güvenini arttırmak hedeflenmektedir. Böylece bireyin bu süreçte yaşadığı değişimi desteklemekle birlikte kendini keşfetmesine imkan sağlarken mutlu olması hedeflenmektedir. Bu araştırmada MEB, okul pansiyonlarında kalan kız öğrencilerde "Yoga Etkinliğinin DDE Çalışmaları Kapsamında Uygulanabilirliğinin" saptanması amaçlanmıştır.

\section{YÖNTEM}

\subsection{Araştırma Modeli}

Gölköy Fatih Anadolu Lisesi kız pansiyonunda kalan öğrencilerde ki yoga etkinliğinin ders dışı eğitim kapsamında ne düzeyde uygulanabilirliğinin incelenmesi konulu araştırmada, katılımcıların bakış açılarından bakabilmeye ve bu bakış açılarını oluşturan sosyal temelleri süreç içinde ortaya koymaya fırsat vermesi nedeniyle deneysel desene bağı nitel bir çalışma yöntemi tercih edilmiştir. Nitel araştırma, insanın kendi sırlarını çözmek ve kendi çabasıyla biçimlendirdiği toplumsal sistemlerin derinliklerini keşfetmek üzere geliştirdiği, disiplinler arası bütüncül bir bakış açısını esas alan bilgi üretme yollarından birisidir (Karataş, 2015; Özdemir, 2010). Araştırma desenini ise "fenomenoloji (olgubilim)" deseni oluşturmuştur. Olgu bilim deseni, "aslında bildiğimiz fakat açıklamada bulunurken bilimsel bulgulara dayalı olarak net söylemler üretemediğimiz olguları, derinlemesine inceleme fırsatı sunan ve zengin söylemler oluşturarak yorumlamalarda bulunma olanağı veren bir araştırma desenidir" (Yaman, 2010).

\section{1 Çalışma Grubu}

2014-2015 Eğitim-Öğretim yılı arasında, Ordu ili-Gölköy ilçesinde bulunan Fatih Anadolu Lisesi okul pansiyonunda kalan $41 \mathrm{kız}$ öğrenci araştırmanın örneklemini oluşturmuşlardır. Bu araştırmada, katıımcı seçiminde yoga etkinliğinin ders dışı eğitim kapsamında uygulanabilirliğinin tespit edilmesi amacıyla, örneklem seçiminde "amaçlı örnekleme" yöntemi kullanılmıştır (Yıldırım ve Şimşek, 2013).

Tablo 1. Katılımcıların profilleri

\begin{tabular}{lcllcl}
\hline Katııımcı & Sınıfı & D.D.E Katıldığı Branş & Katııımcı & Sınıfı & D.D.E Katıldığı Branş \\
\hline K1 & 12 & Akademik & K22 & 11 & Akademik \\
K2 & 12 & Akademik & K23 & 12 & Akademik \\
K3 & 9 & Sportif, Müzik & K24 & 12 & - \\
K4 & 9 & Sportif, Akademik & K25 & 12 & Sportif \\
K5 & 9 & Sportif & K26 & 12 & Akademik, Sportif \\
K6 & 9 & Sanatsal & K27 & 12 & Akademik \\
K7 & 10 & Sportif & K28 & 12 & Akademik \\
K8 & 9 & Sportif & K29 & 12 & Sportif \\
K9 & 11 & Akademik & K30 & 12 & Sportif \\
K10 & 11 & Akademik & K31 & 10 & Sportif, Sanatsal \\
K11 & 12 & Akademik & K32 & 9 & Sportif \\
K12 & 12 & Sportif & K33 & 10 & Akademik, Sportif \\
K13 & 12 & - & K34 & 10 & Akademik \\
K14 & 12 & Sportif & K35 & 10 & Sanatsal \\
K15 & 11 & Sanatsal, Akademik & K36 & 10 & Sportif \\
K16 & 11 & Sanatsal, Akademik & K37 & 10 & Sportif, Sanatsal \\
\hline
\end{tabular}




\begin{tabular}{llllll}
\hline K17 & 11 & Sanatsal, Akademik & K38 & 11 & Akademik \\
K18 & 10 & Akademik & K39 & 11 & Sportif \\
K19 & 11 & Akademik & K40 & 11 & Sportif \\
K20 & 12 & Akademik & K41 & 11 & Sportif \\
K21 & 11 & Akademik & & &
\end{tabular}

\subsection{Araştırma Yapılan Alan ve Uygulamalar}

Bu çalışma Celal Bayar Üniversitesi Etik Kurulu'nun ve Gölköy İlçe Milli Eğitim Müdürlügü̈nün yazılı onayı alındıktan sonra, Ordu ili Gölköy ilçesindeki Fatih Anadolu Lisesi okul pansiyonunda kalan kız öğrencilerin gönüllü katılımları ile gerçekleştirilmiştir. Çalışmaya başlamadan önce okulun konferans salonunda yoga etkinlikleri ile ilgili araştırmacı tarafından bilgilendirme ve tanıtım semineri verilmiş sonra gönüllü olacak katılımcılar belirlenmiştir. Medikal yoga temel olarak nefes egzersizleri, ısınma egzersizleri, gevşemeler, asanalar ve tekrar gevşeme egzersizlerinden oluşan bir uygulamadır. Yoga etkinliği 10 kişilik gruplar oluşturularak, 12 hafta, haftada 2 gün, günde 1 saat uygulanmak üzere, araştırmacı tarafından yaptırılmıştır.

\subsection{Verilerin Toplanması}

Araştırmada, nitel araştırma yöntemlerinden gözlem, görüşme ve doküman analizinden yararlanılmıştır (Yıldırım ve Şimşek, 2013). Bailey'e (1994) göre, araştırmacı bir ortamda oluşan davranışa ilişkin ayrıntılı ve zamana yayılmış bir görüntü elde etmek istiyorsa, gözlem yöntemini kullanabilir. Araştırmada kullanılan gözlem metodu, okul pansiyonunda kalan kız öğrencilerin 12 haftalık, okul ortamında uygulanan etkinlikleri, katılımcıların okuldaki yaşamını ve katılımcı grupların etkileşimlerini oluşturan davranışlarını ayrıntılı olarak tanımlamak amacıyla kullanıımıştır ve tutulan kamera kayıtları ile daha somut veriler elde edilmiştir. Görüşme ilk bakışta kolay bir veri toplama aracı gibi gözükse de yüzeysel ve sıradan konuşmalardan çok farklıdır. Patton’a göre (1987), nitelikli görüşme, beceri, duyarlık, yoğunlaşma, bireyler arası anlayış, öngörü, zihinsel uyanıklık ve disiplin gibi pek çok boyutu kapsaması açılarından hem sanat hem de bilimdir (Yıldııım ve Şimşek, 2013). Görüşme türleri içinden, görüşülen bireylerden toplanan verilerin birbirlerine benzerlikleri ve farklıııkları saptanarak karşılaştırma yapılabilmesi için yapılandırılmış görüşme seçilmiştir. Gönüllü katılım gösteren 41 kız öğrenciye, Yoga çalışması sonucunda "Psikolojik ve fizyolojik kazanımların sağlanması, kendilerine karşı farkındalık geliştirme ve ders dışı farklı etkinlikler uygulama" konularında detaylı görüş ve düşüncelerinin elde edileceği 3 görüşme sorusu sorulmuştur. Görüşme yoga etkinlikleri bittikten sonra yapılmıştır. Görüşmeler bir ses kayıt cihazıyla kaydedilmiş, ayrıca araştırmacı tarafından kısa notlar tutulmuştur. Kaydedilmiş bilgiler araştırmacı tarafından deşifre edilerek bilgisayar ortamında düz yazı haline getirilmiştir. Bu araştırmada, günlük tutulması doküman incelemesi içerisinde yer almaktadır. Günlük, araştırılması hedeflenen olgu veya olgular hakkında bilgi içeren yazılı materyallerin analizini kapsamaktadır (Yıldırım ve Şimşek, 2013). Yoga etkinlikleri öncesinde katılımcılara "Günlük" tutulmasının gereği ve önemi sözlü olarak bildirilmiştir. Yogayla tanışmalarından itibaren 12 haftalık uygulama dönemini, katılııları etkinliklerle ilgili düşüncelerini, hissettiklerini, öneri ve paylaşmak istediklerini yazmaları ve her haftanın sonunda araştırmacıya teslim etmeleri istenmiştir.

\subsection{Verilerin Analizi}

Araştırmada nitel analiz yöntemlerinden betimsel analiz ve içerik analiz yöntemleri kullanılmıştır. Betimsel analiz yöntemi ile elde edilen verilerin anlaşılır bir şekilde çözümlenmesi (kavram ve tema oluşturulması), neden sonuç arasındaki bağın derinlemesine incelenerek bazı sonuçlara varılarak ortaya çıkan bulguların yorumlanması, araştırma sorularına göre sınıflandırılabileceği gibi, veri toplama aşamalarında (gözlem ya da mülakat) elde edilen ön bilgiler ışı̆̆ında da düzenlenebilmesi, kaynaklarından bazı alıntılar yapılması çalışmanın güvenirliğini arttıracağı gibi, çarpıcı görüşlerin yansıtılması amaçlanmıştır (Altunışık ve ark, 2004). Araştırmada görüşme sonucu elde edilen veriler araştırmacı tarafından daha önce belirlenen temalara göre özetlenmiş ve içerik 
analizi ile kodlar ve temalar düzenlenmiştir. İçerik analizi yöntemi ise, verilerin tanımlanması, özetlenen ve yorumlanan verilerin derinlemesine incelemeler sonucu tüm gerçekliğiyle ortaya konması, benzer verilerin temalar ve kavramlarla bir araya getirilmesi için kullanılmıştır (Yıldırım ve Şimşek, 2013). İ̧̧erik analizi yönteminde tümdengelim ya da tümevarım yöntemleri kullanılabilir (Elo ve Kyngas, 2008: 109, 111). Araştırmada yoga etkinliğinin ders dışı eğitim çalışmaları kapsamında değerlendirildiğine dair temel bir bilgi bulunmamaktadır. Bu nedenle araştırma da analiz yöntemi olarak tümevarım yöntemi tercih edilmiştir. Görüşme, gözlem ve doküman analizi (günlük) yoluyla elde edilen veriler ses kayıt cihazı kullanılarak kaydedilmiştir. Kaydedilen veriler elektronik ortamda düz yazı haline getirilerek "Nvivo 10 for Windows" programı aracıllğı ile kodlanmıştır.

\subsection{Geçerlik ve Güvenirlik}

Nitel araştırmada geçerlik, bir ölçme aracının ölçmeyi amaçladığı özelliği başka özelliklere karıştırmadan, doğru olarak ölçebilme derecesidir ve geliştirilmiş olduğu konuda maksada hizmet etmesidir (Yılmazer, 2012; Büyüköztürk, 2007). Güvenirlik ise bir ölçme aracı neyi ölçüyorsa ya da neyi ölçmek için hazırlanmışsa onu, kararlı bir şekilde ölçmesi ve anlamda yapılan ölçmelerin hatalardan arınıklık derecesidir (Karataş, 2015). Farklı yöntemlerle (görüşme, gözlem, doküman analizi gibi) elde edilen verilerin birbirlerini teyit amacıyla kullanılması, ulaşılan sonuçların geçerliğini ve güvenirliğini arttırmaktadır (Yıldırım ve Şimşek, 2013). Bu araştırmada çeşitleme ölçütü olarak; araştırmacının katılımcı olarak gözlem ve görüşme yapması, alan notu elde etmesi, günlüklerin kız öğrenciler tarafından yoga etkinliğine katılıktan sonra gün içinde istedikleri zaman düzenli olarak yazılması, kamera ile ses kaydı ve fotoğraf çekimi kullanılmıştır. Araştırmanın güvenirliğinin sağlanması aşamasında basit uyum ve kappa katsayıları hesaplanmıştır. İki ya da daha fazla araştırmacının yaptığı değerlendirmeler için aynı veya değişik inceleme araçları kullandığı durumlarda uyumluluğunu belirlemek için Cohen'in Kappa istatistiği kullanılmıştır (Kılıç, 2009). Kappa güvenirlilik katsayısı hesaplanmış ve güvenirlilik katsayısı 0.76 olarak tespit edilmiştir. Bu bulgular hesaplanan değerlerin, puanlayıcılar arasında iyi düzeyde uyumlu olduğunu göstermektedir.

\section{BULGULAR}

Yapılan istatistiksel çalışmalar ve analizler neticesinde, MEB, okul pansiyonlarında kalan kız öğrencilerde, yoga etkinliğinin ders dışı eğitim çalışmaları kapsamında uygulanabilirliğinin incelenmesi çerçevesinde elde edilen verilerin analizi "demografik özelliklere ilişkin bilgiler" ve "çeşitleme yönteminin (gözlem, görüşme ve doküman) verilerinin analizi" şeklinde gerçekleşmiştir.

Tablo 2. Katılımcıların Demografik Sorulardaki Etkinliklere ilişskin Frekans ve Yüzde Dağılımı

\begin{tabular}{llcc}
\hline Etkinlikler & & $f$ & $\%$ \\
\hline \multirow{3}{*}{ Katıldığı ders dışı etkinliklere devam etme } & Evet & 17 & 41.4 \\
& Hayır & 24 & 58.6 \\
& Toplam & 41 & 100 \\
\hline \multirow{3}{*}{ Aile veya çevresinde çeşitli etkinliklere katılma } & Evet & 11 & 26.9 \\
& Hayır & 30 & 73.1 \\
& Toplam & 41 & 100 \\
\hline \multirow{2}{*}{ Katıldığı ders dışı etkinlikleri önerme } & Evet & 26 & 63.4 \\
& Hayır & 15 & 35.6 \\
& Toplam & 41 & 100 \\
\hline
\end{tabular}

Tablo 2 incelendiğinde; katılımcılardan daha önce katıldıkları etkinliklere devam etme ile ilgili 17 kişi (\%41.4'ü) evet yanıtı, 24 kişi (\%58.6'sı) hayır yanıtını vermişlerdir. Katılııları bu etkinlikleri önerme sorusuna 26 kişi (\%63.4'ü) evet derken, 15 kişi (\%35.6'sı) hayır yanıtını vermişlerdir. 'Aile 
veya çevresinde çeşitli etkinliklere katılan var mı?' sorusuna ise 11 kişi (\%26.9'u) evet derken, 30 kişi (\%73.1'i) ise hayır yanıtını vermişlerdir.

Tablo 3. Katılımcıların Demografik Sorulardaki Ailelerine Illişkin Frekans ve Yüzde Dağılımı

\begin{tabular}{|c|c|c|c|}
\hline Aile & & $f$ & $\%$ \\
\hline \multirow{5}{*}{ Yaşadığı yerleşim yeri } & Köy & 16 & 39 \\
\hline & Belde & 4 & 9.8 \\
\hline & İlçe & 17 & 41.4 \\
\hline & il & 4 & 9.8 \\
\hline & Toplam & 41 & 100 \\
\hline \multirow{4}{*}{ Ekonomik durum } & Zayıf & 2 & 4.9 \\
\hline & Orta & 28 & 68.2 \\
\hline & İyi & 11 & 26.9 \\
\hline & Toplam & 41 & 100 \\
\hline \multirow{6}{*}{ Anne eğitim } & Eğitim almamış & 8 & 19.6 \\
\hline & illkokul & 24 & 58.5 \\
\hline & Ortaokul & 6 & 14.6 \\
\hline & Lise & 2 & 4.9 \\
\hline & Üniversite & 1 & 2.4 \\
\hline & Toplam & 41 & 100 \\
\hline \multirow{6}{*}{ Baba eğitim } & Eğitim almamış & 3 & 7.5 \\
\hline & ilkokul & 19 & 47.5 \\
\hline & Ortaokul & 5 & 12.5 \\
\hline & Lise & 11 & 27.5 \\
\hline & Üniversite & 2 & 5 \\
\hline & Toplam & 40 & 100 \\
\hline \multirow{6}{*}{ Anne meslek } & Ev hanımı & 33 & 80.4 \\
\hline & Çiftçi & 2 & 4.9 \\
\hline & İşçi & 2 & 4.9 \\
\hline & Serbest meslek & 4 & 9.8 \\
\hline & Memur & - & - \\
\hline & Toplam & 41 & 100 \\
\hline \multirow{6}{*}{ Baba meslek } & İşsiz & 3 & 7.5 \\
\hline & Çiftçi & 8 & 20 \\
\hline & İşçi & 7 & 17.5 \\
\hline & Serbest meslek & 18 & 45 \\
\hline & Memur & 4 & 10 \\
\hline & Toplam & 40 & 100 \\
\hline
\end{tabular}

“Katılımcıların birisinin babası hayatta olmadığından toplam sayı 40'a düşmüştür.

Tablo 3 incelendiğinde; katılımcıların ailelerinin \%39'u köyde, \%9.8'i beldede, \%41.4'ü ilçede ve \% 9.8'inin de ilde yaşadığı tespit edilmiştir. Ekonomik durumlarına ilişkin bulgular değerlendirildiğinde ise $\% 4.9$ 'u zayıf, $\% 68.2$ 'si orta ve $\% 26.9^{\prime}$ unun iyi olduğu görülmüştür. Anne eğitim durumu değişkeninde en düşük üniversite \%2.4 iken en yüksek ilkokul \%58.5'tir. Baba eğitim durumu en düşük üniversite $\% 5$ iken en yüksek ilkokul $\% 47.5^{\prime}$ tir. Anne mesleği incelendiğinde memur olan kesime rastlanmamış olup, en yüksek ev hanımı \%80.4'tür. Baba mesleği en düşük işsiz \%7.5 iken en yüksek serbest meslek \%45'tir. 
Çeşitleme yönteminin (gözlem, görüşme ve doküman) analizi sonucunda elde edilen verilerin analizi sonucunda okul pansiyonlarında kalan kız öğrencilerin yoga etkinlikleri ile psikolojik kazanımlara, fizyolojik kazanımlara ve farkındalığa ilişkin algıları ve düşüncelerine yönelik bulgular Model 1-2 ve Şekil 1'de sunulmuştur.

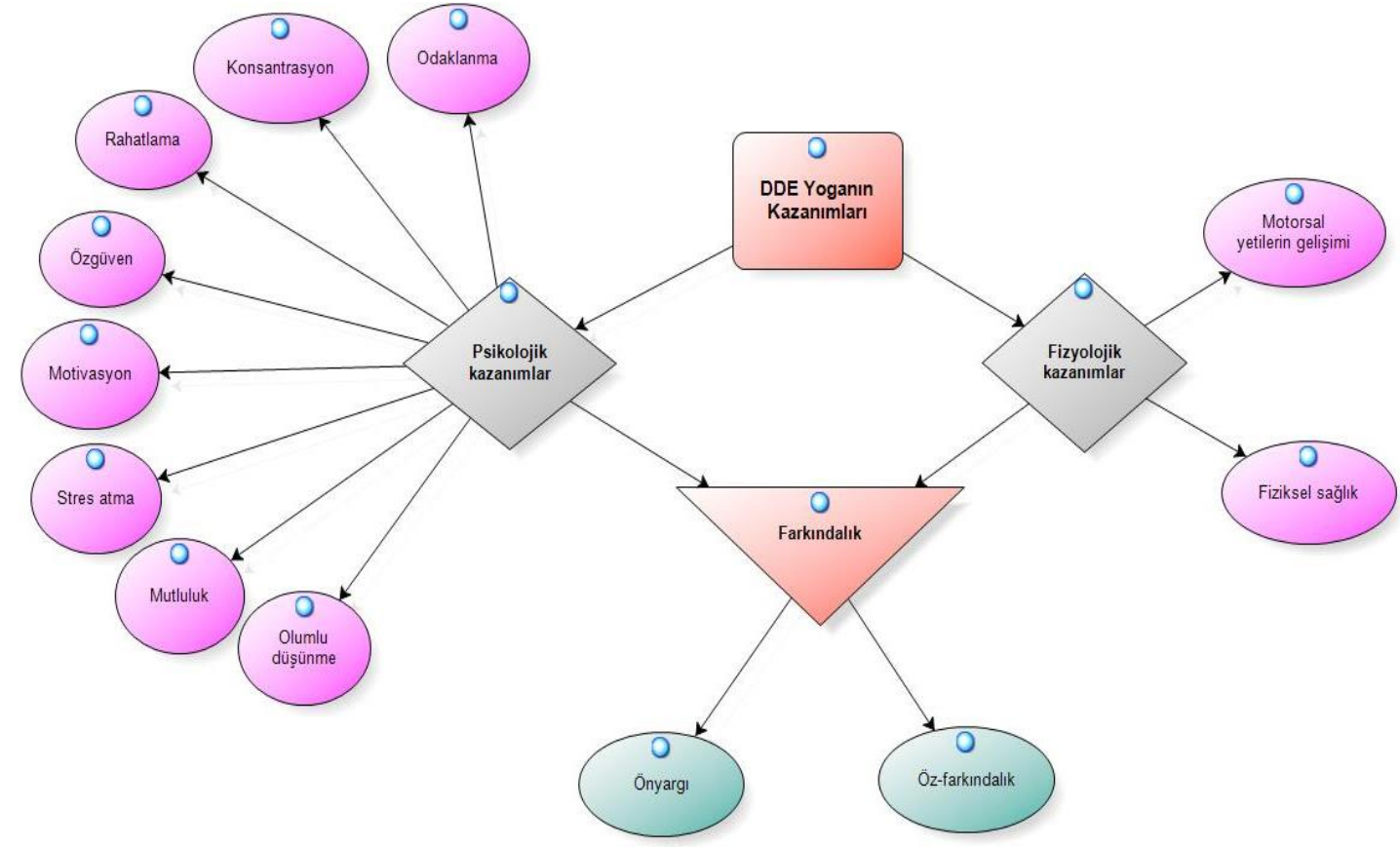

Şekil 1. Model-1; ders dışı etkinlikler kapsamında ortaya çıkan temalar

Model 1'e göre katıımcılar DDE olarak yoganın kazanımlarına ilişkin görüşlerini ilk olarak psikolojik kazanımlardan "odaklanma, konsantrasyon, rahatlama, özgüven, motivasyon, stres atma, mutluluk ve olumlu düşünme" temaları üzerinde dururken, ikinci olarak ise fizyolojik kazanımlara ilişkin "motorsal yeti gelişimi ve fiziksel sağlık" temalarına dair veriler elde edilmiştir. Üçüncü ve son temada ise katılımcılar farkındalığa ilişkin "önyargı ve öz-farkındalık" temaları üzerinde durarak görüşlerini belirtmişlerdir.

Gözlem, görüşme ve doküman analizlerinden (günlük) elde edilen verilerin analizi sonucunda okul pansiyonlarında kalan kız öğrencilerde ders dışı eğitim önerisi olarak "Yoga"nın ortaya çıkarttığı kazanımlara ilişkin altı (6) tema elde edilmiştir (Model 2). 


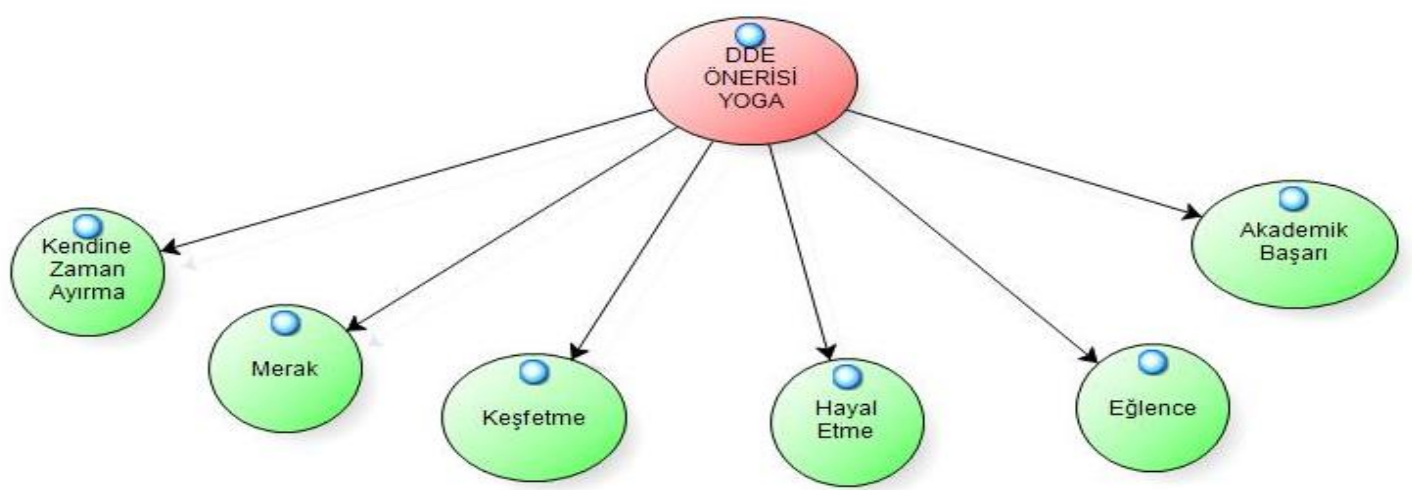

Şekil 2. Model-2; yoga uygulamalarının kız öğrencilerde ortaya çıkarttığı kazanımlara ilişkin temalar

Model 2'de elde edilen bulgulara göre katılımcılar görüşlerini "kendine zaman ayırma, merak, keşfetme, hayal etme, eğlence ve akademik başarı" temaları üzerinde durarak belirtmişlerdir.

\section{SONUÇ VE TARTIŞMA}

\subsection{Demografik özelliklere ilişkin sonuçlar}

Katılımcıların ders dışı etkinliğe ilişkin bulgular bölümündeki demografik veriler ışığında öğrenciler akademik başarıyı arttırıcı ders dışı etkinlikler dışında ilgi ve isteklerine uygun sosyal ve spor etkinliklerinin açılmamasından şikâyet ederken ayrıca serbest zamanlarını değerlendirerek pasif yaşantıdan uzaklaşmak için fiziksel aktivite yapacak uygun tesis ve araç-gereç eksikliğinden de yakınmaktadırlar. Ayrıca katılımcıların ailelerinin herhangi bir taleplerinin olmaması, okullarda ders dışı etkinliklerin yetersiz ve çeşitlendirilmemiş olmasının da rol oynadığı düşünülebilir. Gökalp (2007) katılımcıların serbest zamanlarını değerlendirmek için istediği gibi bir etkinliğin olmadığını, yapılan programların kendisine uymadığını, uygun programların olmaması gibi şartlardan dolayı serbest zamanlarını değerlendiremediklerini belirtmiştir. Gençlerin serbest zamanlarında en iyi şekilde yapabilecekleri ve yeteneklerine uygun etkinliklere yönlendirilmesi toplumsal ve sosyal anlamda ülke gelişmişliğini de katkı sağlayacağı söylenebilir. Akkaya (2008)'nın çalışmasında öğrenciler serbest zamanlarını daha çok pasif şekilde değerlendirdiklerini belirtmişlerdir. Katılımcıların ailelerinin ekonomik durumları \%68.2 ile orta düzeyde olup \%39'u köyde ve \%41.4'ü ilçede yaşamaktadır. Annelerinin \%58.5'i ilkokul mezunu olarak meslek seçiminde $\% 80.4$ 'ü ev hanımlığını tercih etmiştir. Babalarının \%47.5 ile çoğunluğu anneleri gibi ilkokul mezunu olarak \%45'i serbest meslek yapmaktadır. Çakıroğlu (1987)'na göre; bir kişiyi belirli bir amaca yöneltmek ve aktif hale getirmek için en geçerli faktörlerden birisi aileden kaynaklanan motivasyondur (Gökalp, 2007) ve aileler çocuklarının derslerinden geri kalacağı düşüncesiyle spordan uzaklaştıracaklarına, onların günlük hayatlarını iyi organize etmeyi, zamanlarını israf etmeden faydalı amaçlarla kullanmayı öğretmelidirler. Böylece ders, spor, dinlenmek, eğlenmek için zamanını iyi ayarlayan çocuk ve gençler hem derslerinde hem de spor faaliyetlerinde başarılı olabileceği söylenebilir. Dolayısıyla ailelerin spora bakış açıları da daha olumlu olacağı düşünülmektedir (Akgül, Göral ve ark. 2012). Ergenlerin yaşam becerilerinin desteklenmesi, düzenli fiziksel aktivite yapma konusunda teşvik edilmeleri ve okul pansiyonlarındaki serbest zamanlarını daha aktif geçirmek için olanakların iyileştirilmesi, ruh sağlığının geliştirilmesi açısından önemli gözükmektedir.

\section{2 Çeşitleme Yöntemi ile elde edilen verilerin analizine ilişkin sonuçlar}

Çeşitleme yöntemi ile (gözlem, görüşme ve doküman analizi) elde edilen verilerin analizi sonucunda; her birinde ortak olan iki (2) ana tema bulgular bölümünde verilmiştir. Bu temalar; ders dışı eğitim olarak yoganın kazanımları ve ders dışı eğitim önerisi olarak yoganın kazanımlarıdır. Bununla birlikte DDE olarak yoganın kazanımlarına ilişkin üç (3) ortak temaya 
ulaşılmıştır. Bunlardan ilki psikolojik kazanımlardan "odaklanma, konsantrasyon, rahatlama, özgüven, motivasyon, stres, mutluluk ve olumlu düşünme" ortak temaları üzerinde dururken, ikinci olarak ise fizyolojik kazanımlara ilişkin "motorsal yeti gelişimi ve fiziksel sağlık" ortak temalarına ulaşılmıştır. Üçüncü ve son ortak tema ise farkındalığa ilişkin "önyargı ve öz-farkındalık" temalarıdır. DDE önerisi olarak yoganın kazanımlarına ilişkin olarak altı (6) ortak temaya ulaşılmışır. Bu temalar; "kendine zaman ayırma, merak, keşfetme, hayal etme, eğlence ve akademik başarı"dır.

\subsubsection{Ders dışı eğitim olarak yoganın kazanımları}

\subsubsection{Psikolojik kazanımlar}

Rahatlama; Beden ve zihin sürekli baskı altında olduğundan, gün içindeki ritüeli sürdürebilmek için gerekli olan enerjiyi zaman içinde boşa tüketmek olarak açıklanan kavram Bagchi ve Wenger; 1957, ve Schultz ve ark.; 2011) tarafından yapılan çalışmalarda katılımcıların sinir sisteminde yoganın psikolojik olarak derin bir rahatlama sağladığı, bel ağrısını ve stresi azalttığı, farkındalığı artırdığını, postürü düzelttiği, daha iyi bir uyku ve gevşeme sağladığı belirtilmiştir. Araştırma da ise kız öğrencilerin yoga etkinliklerinde asanaları (hareketleri, duruşları) yaptıkça rahatladıkları gözlemlenmiştir. Özellikle etkinliğin son kısmı olan derin gevşeme sürecinde komutlarla sağlanan konsantrasyon ile nefes alıp-vermeye odaklanılmakta ve yönteme uygun olarak hareket edilerek, fiziksel ve zihinsel rahatlamanın gerçekleştiği görülmüştür. Bedenlerindeki rahatlama sonucunda kız çocuklarının daha sakin, daha enerjik, bir konu üzerine dikkatini daha iyi toplayabilen, duygusal açıdan daha dingin ve kontrollü oldukları söylenebilir.

Stres; Stres kontrolünü sağlamak amacıyla geliştirilmiş birçok bireysel yöntem vardır. Bunlardan birisi de yogadır. Yoga çalışmalarının sonucunda yoganın stres ve depresyonu azaltmada ve genel iyilik halini artırmada etkili olabileceği kanısına varılmıştır (Simard ve Henry; 2009, Schultz ve ark.; 2011; Stueck ve Gloeckner; 2005). Bu araştırma sonucunda ise kız öğrencilerin, gün içinde yaşadıkları olumsuzlukları sorun haline dönüştürerek stres faktörü oluşturdukları, gerek okul yaşantıları (dersler, sınavlar, vb.) gerekse adölesan dönemde olmaları nedeniyle stres faktörünün daha da arttığı elde edilen veriler ışığında söylenebilir. Düzenli yapılan yoga etkinlikleri ile uygulanan asanaların (hareketlerin, duruşların) öğrencilerin vücutlarını çok yönlü çalıştırarak, meditasyon ve derin gevşeme ile bütünleştirdiği, daha sakin ve rahatlamış bireyler haline geldikleri gözlemlenmiştir.

Odaklanma; Yapılan araştırmalarda solunuma odaklanmanın sürekli solunumu düşünmek olmadığını, onu hissetmek ve solunumdaki değişimler açısından farkında olmak olduğunu belirtmiş, solunum sırasında karna odaklanmanın sakinleştirici tarafından ve karın solunumunun daha doğal, yavaş ve derin olduğu için stresle baş etmede göğüs solunumuna göre daha etkin olabileceğine değinilmiştir. Yoga, katılımcıların esnekliklerinde ani artışa ve bedenleri üzerinde bir miktar kontrol sahibi olmalarına yardımcı olduğu için somatik ya da fiziksel yakınmaları olan bireylerde özellikle yararlıdır (Körükçü ve Kukulu, 2015). Bu araştırmaya katılan kız öğrenciler yoga yaparken hareketlere odaklanmalarının onları o anı yaşamaya yönelttiğini ve zihinlerine o gün yaşadıkları kötü olayların gelmediğini belirtmişlerdir. Yogada kazandıkları odaklanma becerisiyle derslerine daha iyi çalıştıklarını ifade etmişlerdir.

Konsantrasyon; Davidson ve ark. (2003) araştırmalarında bireyin bedeni ile bağlantı kurmasını sağlayan en güçlü yöntemlerden birisi bireyin bedeni üzerine kapsamlı ve anlık odaklanmasıdır, bu da bireyin aynı anda hem konsantrasyonunu, hem de bedeni konusunda zihinsel esneklik geliştirmesine olanak sağlamaktadır. Khalsa ve Gould (2012) araştırmasında katılımcılar yoga ve meditasyon yöntemleri sayesinde stresle başa çıkma, hafıza, konsantrasyon ve anlama kabiliyetini geliştirdiği sonucuna ulaşmışlardır. Kız öğrenciler hareketleri yaparken dengede durmakta zorlandıklarını, bir işe ve özellikle sınav anında yaşadıkları stres sonrası konsantrasyon sağlamakta zorlandıklarını belirtmişlerdir. Katılımcılar yoga sonrasında yaptıkları işe ve derslerine daha iyi konsantrasyon gerçekleştirdiklerini söylemişlerdir. Ayrıca dengelerinde de eskiye göre gözle görülebilen bir gelişim gözlemlenmiştir. 
Özgüven; Tran ve ark. (2001) araştırmasına göre kendine, kendi bilgeliğine ve erdemine güvenme tutumu meditasyon uygulamasının önemli bir unsurudur. Kabat-Zinn (2003) araştırması sonucunda; yoga egzersizleri sırasında bedenin bireyin durması gerektiği noktayı ve esnetme egzersizlerini sonlandırmasını söylemesi, kişinin bedenin sesine güven duymasını tetiklemektedir. Egzersizler sırasında duygularına güvenmeyen birinin bedenine zarar vermesi kaçınılmazdır. Yapılan araştırmalar, fiziksel aktiviteye katılımın özellikle adölesanlarda ve kadınlarda kendine güven duygusu geliştirdiğini, kaygı ve stres düzeylerini azalttığını göstermektedir (Ildız; 2014, Ülger ve ark.; 2007). Bu araştırma sonucunda, kız öğrenciler fiziksel olarak farkındalıklarının yükseldiğini, bedenlerini daha iyi tanıdıklarını ve bunun da özgüvenlerini arttırdığını belirtmişlerdir. Yoga ile kendine güvenleri gelen kız öğrencilerin yaşantılarının her alanında ve her aşamasında kazandıkları bu gücün gelecekteki başarılarına da yansıyacağı söylenebilir.

Olumlu düşünme; Taşpınar (2010)'ın araştırmasında yoga alıştırmalarının sinir sistemini güçlendirip, arındırdığl; böylece dünyayı bilinçli ve olumlu bir tutum içinde ve net olarak algılayarak etkileşime geçmenin mümkün olacağı sonucuna ulaşılırken, Çı̆̆ın'ın (2007) Hakkari ilinde yapmış olduğu bir araştırmasında katılımcılarını bulundukları ortamdan çıkartıp sporsal faaliyetlere ve sosyal etkinliklere yönlendirmesi sonucunda, onların geleceğe ve hayata bakışlarını daha olumlu hale geleceğine dair olumlu düşünmeye başladıklarını ifade ettikleri görülmektedir. Benzer bir sonuç ile bu çalışma katıımcıları, yoga ile hayatlarında yaşadıkları olumsuz şeylerden arındıklarını, yoga sonrasında da bu etkinin günlük yaşamlarına da yayıldığını belirtmişlerdir. Yoga etkinlikleri sonucunda edinilen bu olumlu tutumun kız öğrencilerin kendilerine olan inançlarını arttırarak daha başarılı bireyler haline gelmelerine yardımcı olacağı söylenebilir.

Mutluluki Yoganın en önemli amaçlarından biri, başkalarının arasında sağlık ve mutluluk içinde yaşayacak mükemmel ve bütünleşmiş insanı yaratmaktır. Bu da ancak sakin ve temiz bir zihne ulaşma veya bilincin üstüne çıkma ile elde edilir (Baş, 1998). Fishman (2003)'a göre yoga etkinlikleri ilk olarak aklı sakinleştirme, huzura kavuşturma bilimi olarak başlamıştır ve her yoga yaklaşımı bilinçlilik halini geliştirmeyi ve yaşamda karşılaşılan durumlardan etkilenmemeyi araştırmaktadır (Taşpınar, 2010). Oken ve ark. (2006)'nın araştırmasında ise yoga grubunda fiziksel ölçümler, yaşam kalitesiyle ilgili iyi olma, enerji seviyesinde artış ve yorgunluk hissinde azalma düzeylerinde diğer gruplarla karşılaştırıldığında daha fazla artış meydana gelmiştir. Sonuç olarak yoganın fiziksel ve mental sağlığı iyileştireceği, böylece iyilik halini artıracağı kanısına varılmıştır. Bu araştırma da katılımcılar, kendilerine zaman ayırarak yoga ile günlük yaşamın getirdiği stresten, yorgunluktan bedenlerini ve zihinlerini kurtararak rahatladıklarını belirtmişler. Bu rahatlama sonucu yoga da geçirdikleri eğlenceli anların beraberinde mutluluğu getirdiğini söylemişlerdir. Sağlığın korunması, geliştirilmesi ve gelecekte daha sağlıklı toplumlar oluşması için düzenli olarak egzersiz yapılmasının önemli olduğu söylenebilir.

Motivasyon; Allen (2003)'ın araştırmasında sporda bireylerin motivasyonunun her zaman fiziksel yeteneğini göstermek ya da geliştirmek isteği ile ilgili olmadığını, sosyal bağları geliştirmek gibi sosyal konuların da gençlerin spora katılım motivasyonlarını anlamada önemli olduğunu sonucuna ulaşmıştır. Ayrıca takım üyeliği, bir takımın parçası olmak ve sosyal statü gibi sosyal konuların, katılımcıların motivasyonlarında çok belirgin olduğunu da savunmuştur. Güdülenmedeki artış, öğretmen ve öğrencilerin okuldan daha çok haz duymalarına imkan sağlamaktadır. Bu araştırma sonucunda da yapılan araştırmaları destekleyici bir şekilde katııımcılar yogadaki rahatlamanın sonrasındaki ders çalışmalarında motivasyonlarını arttırdığını belirtmişlerdir. Ayrıca katılımcılar yogaya katılım motivasyonlarında fiziksel ve zihinsel gelişimlerinin yanında sosyal olarak bir gruba dahil olmanın da etkin olduğunu söylemişlerdir. Yoga ile kız öğrencilerin çoğunun kendi özelliklerinin farkına varmaya başlaması, öğrenim görme nedeninin bilincine varması ve uygun motivasyon kaynaklarının işe koşulması sonucunda bireyin başarılı olma yolundaki çabasını daha da arttıracağı söylenebilir. 


\subsubsection{Fizyolojik kazanımlar}

Motorsal yeti gelişimi; Yoga, görsel ve işitsel reaksiyon süresinin azalmasına neden olmaktadır. Telles (1993) yaptığı çalışmalar ile yoganın gençlerde statik motor performansı arttırdığını göstermiştir. Bunu, el göz koordinasyonu, ince motor kontrolü ve konsantrasyonu geliştirerek sağladığı düşünülmektedir (Baş, 1998). Yoga yapan bireylerde çabukluk, kas gelişimi ve hızda önemli bir artış olduğu ve fiziksel sağlığın gelişimine çok önemli bir katkısı gözlemlenmiştir. Barry ve ark., erkek ve kadınlara değişen sürelerde yapılan programların fiziksel ölçüm yapılarak değerlendirilmesi sonucunda, bütün gruplar içerisinden anlamlı artış en çok yoga grubunda gözlemlenmiştir (Ülger ve ark. 2007). Tran ve ark. (2001) çalışmasında kas kuvveti ve esneklik üzerine yoganın etkilerini araştırmak üzere yaptıkları çalışma uygulanan yoganın kas kuvveti ve esnekliği arttırdığı kaydedilmiştir. Bu çalışmada yapılan uygulamalar sonucunda kız öğrencilerinin postür bozukluklarının azaldığı gözlenmiş ve konu ile farkındalıkları oluşmuştur. Bazı öğrencilerin esneklik ve kas yoğunlukları artarken bazılarında hareketleri yapabilme yetisinin arttığı gözlemlenmiştir. Düzenli yoga etkinlikleri ile kız öğrenciler kazandıkları yeni motorsal yetileri kaybetmeden korumaları ve hatta ileride yogayı bir yaşam tarzı haline getirmeleri yönünde zihinlerinde bir düşünceye neden olduğu söylenebilir.

Fiziksel sağlıki Baş (1998)'ın gençlerde postür ve fiziksel uygunluk üzerine etkileri çalışmasında vücut ağırlığında ve vücut kitle indeksi değerlerinde azalma gözlenmiştir. Yarcheski ve Mahon (1997) araştırmasında yoganın çok yönlü kronik hastalıklarla; kalp, diyabet, kanser gibi başa çıkma konusunda büyük bir potansiyeli olduğu sonucuna ulaşmıştır. Gençler arasında yoganın psikolojik, sosyal, bireysel ve fiziksel sağlığı arttıııı bir özelliğe sahip olduğu ortaya çıkmıştır. Datta ve Broota (2000), Rani ve Rao (2005), Rao (2000)' nun araştırmalarına göre yoga klinik tedavisinde koruyucu ve şifa verici etkisiyle yeni bir terapi olarak ortaya çıkmaktadır. Bu araştırma sonuçlarına göre kızlarda kilo kaybı ve bedensel incelme gözlenmiştir. Yoga etkinlikleri öncesinde kızlar sedanter yaşam tarzını benimsediklerini ve sağlıksız yiyeceklerle beslenerek serbest zamanlarını bu tip etkinliklerle boşa harcadıklarını belirtmişlerdir. Katılımcılar yoga ile bedensel egzersiz yaparak zamanlarını daha verimli geçirdiklerini araştırma sonucunda vurgulamışlardır. Yoga ile fiziksel sağlıklarına kavuşan ve bunun önemini kavrayan katılımcıların yaşamları boyunca bu bilinçle devam edebilecekleri söylenebilir. Ayrıca bu bilinci çevrelerine de yayabilecekleri düşünülmektedir.

\subsubsection{Farkındalık}

Önyargl; Cüceloğlu, (1999) çalışmasında "seçimlerimizden, verdiğimiz kararlara kadar farkında olmadan önyargılarımızın etkisi altında olabileceğimizi belirtirken olumsuz önyargıların oluşumunda, geniş grup dinamiklerinin büyük rolü olduğuna ve gibi önyargının olumsuz bir tutum olup, birçok sosyal durumda kendini gösterebildiğine" değinmiştir. Destekleyici bir sonuç ile bu araştırmaya katılan kız öğrencilerin yoga etkinliğine ilk geldikleri zaman çekingen oldukları gözlemlenmiştir. Yoga ile ilgili bilgileri sınırlı hatta yok denecek kadar az olmakla birlikte duyum ve görmüşlüklerinden çok daha farklı olduğunu belirtmişlerdir. Katılımcı öğrencilerin hareketleri yapmayla ilgili önyargılı oldukları saptanmıştır. Yoga eğitimi süreci sonucunda ise bu önyargılarından uzaklaştıklarını belirtmişlerdir. Ayrıca öğrenciler yogaya katılmakla ilgili dini söylemlerden ötürü belirgin bir önyargıya sahip olduklarını eğitim öncesi süreçte belirtmişlerdir. Yoga etkinliği kız öğrencilerin önyargılarının yıkılmasına sebep olurken, birbirleriyle daha etkili bir iletişim kurmalarına ve yeni karşılaştıkları durumlara karşı daha pozitif bir algı oluşturmalarına neden olduğu söylenebilir.

Öz-farkındalık; Duyan (2008) tarafından yapılan çalışma yaşamında yoganın etkileri araştırmasında bireylerin anlık tepkilerinin eskiye nazaran daha ılımlı olduğu sonuçlarına ulaşıırken, daha sakin ve huzurlu olma ortak görüşleri de belirtilen ifadeler arasında yer almaktadır. Fiziksel kuvvetlerinin geliştiğini söyleyen katılımcılar aynı zamanda farkındalıklarının artmasıyla daha duyarlı ve yaptıkları işe daha konsantrasyon sağladıklarını belirtmektedirler. Acara (2012)'nın Avustralya Beden Eğitimi ve Sağlık Müfredatı ile ilgili araştırmasında da benzer sonuçlara ulaşıımış yapılan 
fiziksel etkinliklerle katılımcıların öz-farkındalıkları gelişerek, fiziksel ve psikolojik olarak farklılık gözlemlenmiştir. Singh ve Misra (2015) araştırmasında gençlerin karakteristik özelliği olan psikolojik kargaşa (okulda her gün görülebilecek hayal kırıklığı, anksiyete, çatışma gibi) anlarında yoganın sağlıklı olma konusunda önemli yardımları olduğu sonucuna varmışlardır. Katııımcıdaki psikolojik kargaşanın ortadan kalkarak kendini, yeteneklerini, ilgi duyduğu konuları anlaması yoga ile farkındalık arasında güçlü bir ilişkinin olduğunu göstermektedir. Böylece katıımcı kariyeri ile ilgili kararları daha sağıkı verebilir. Yoga eğitimi süreci sonucunda bu araştırma katılımcıları kendilerine zaman ayırarak fiziksel özelliklerinin yanında zihinsel ve ruhsal açıdan da kendilerini tanıma imkanı bulmuşlardır. Yoga ile katıımcı öğrenciler olumlu-olumsuz yönlerinin farkına vararak duygu ve düşüncelerinin değişimlerini fark edip kendilerini ve çevrelerindeki bireyleri hatta durumları olduğu gibi kabul etme bilincine ulaşmışlardır. Yapılan bu araştırma sonuçlarında; kız öğrencilerin yoga etkinlikleri ile kendi bedenlerini yavaş yavaş tanıdıkları gözlemlenmiştir. Öğrencilerin kendi bedenlerini tanıdıkça güçlü ve zayıf yönlerini keşfettikleri ve hatta bedenlerini ne kadar zorlayabileceklerinin de bilincine vardıkları elde edilen veriler ışığında söylenebilir. Yoga etkinliği kız öğrencilerin öz-farkındalıklarını geliştirerek hem fiziksel hem de psikolojik olarak kendilerini daha iyi tanımalarına yardımcı olarak farklı bakış açıları kazanmalarına ve çevresiyle barışık, geleceğe kendinden emin, sosyal bir birey olarak ilerlemesine yardımcı olduğu söylenebilir.

\subsubsection{Ders dışı eğitim önerisi olarak "Yoga"nın kazanımları}

Kendine zaman ayırma; Zamanı verimli bir şekilde planlayarak bireyin fizyolojik intiyaçları ve para kazandığı işi dışında kendine zaman ayırması çok önemlidir. Kalkavan ve ark. (2006)'nın yaptığı bir araştırmada iyi bir eğitim alabilmek gayesiyle, özel kursları takip etmeleri, yoğun sınav maratonuna hazırlanmaları, spora ayıracak zamanlarının olmamasının, öğrencilerde spor merkezlerine, okul içi ve okullar arası spora olan ilgiyi azaltmaktadır. Fakat spor, çocuğun çok yönlü gelişmesinde ve sosyalleşmesinde önemli rol oynadığı için erken yaşlarda spora başlanması tavsiye edilmektedir (Akgül, Göral ve ark. 2012). Ülger ve ark.(2007)'nın esneklik ve denge üzerine yaptıkları çalışmada iş stresi ve sedanter yaşam biçiminden kurtulma amacı ile yogaya katılan kadınların kendilerine kısada olsa zaman ayırmanın üzerlerinde hissettirdiği olumlu geri bildirimleri ortaya koymaktadır. Kız öğrencilerin yoga ile farkındalıkları gelişerek ders çalışmak dışında fiziksel etkinlikler ile kendilerine zaman ayırmaları gerektiğinin bilincine vardıklarını belirtmişlerdir. Kendine zaman ayırmanın önemini kavrayan katılımcıların mezun olduktan sonra gerek üniversite gerekse iş yaşantılarında zamanlarını daha iyi planlayarak stresin yaratabileceği olumsuz etkilerinden etkilenmeden sağlıklı bir yaşam sürecekleri söylenebilir.

Merak; Budak (2000)' göre merak, insandaki temel öğrenme biçimlerinden birisidir ve 3-4 yaşlarındaki çocukların " bu ne? " türünden bitip tükenmez sorularıyla doruğa ulaşır. Çok erken yaşta başlaması ve hayvanlarda da gözlenmesi nedeniyle genellikle merakın doğuştan, öğrenilmemiş bir güdü olduğuna inanılır (Akgül ve Özdilek, 2014). Katılımcılar yoga hakkındaki bilgilerinin sınırlılığı nedeniyle merak duygularının oluştuğunu belirtmişlerdir. Ayrıca yoganın diğer fiziksel aktivitelerden farklı olması da katılımcıların merak duymasına neden olmuştur. Yoga ile ilgili edindikleri bilgiden sonra katıımcıların merakının giderildiği söylenebilir. Katılımcıların yoga etkinliklerine katıldıkça bedenlerini tanıma merakının daha da arttı̆̆ı, yeniliklere ve öğrenmeye karşı olumlu tutuma sahip oldukları, merak ettikleri konularla ilgili fırsat ve olanakları değerlendirmeye açık oldukları, söylenebilir.

Keşfetme; Kabat-Zin (2009)'de her bir meditasyon uygulamasında yapılan işlem aynı olsa dahi, hissedilen duyguların, uygulamalar sırasındaki ruh halinin farkında olmak ve acemi bir zihin ile faaliyetleri yerine getirmek gerektiği sonucuna ulaşmıştır. Katılımcılar her yoga etkinliğinde zihinsel olarak sanki bedenlerini yeniden keşfettiklerini belirtmişlerdir. Ayrıca yeni bir etkinliği keşfediyor olmaktan da büyük keyif aldıklarını söylemişlerdir. Yoga etkinlikleriyle kendini keşfeden, sınırlarını ve kalıplarını yıkarak yeni bir karakter inşa eden bir bireyin hayattan ne istediğini bileceği söylenebilir. 
Hayal etme; Gregg ve Hall (2006) golf sporcusu üzerinde yaptıkları çalışmada hayal etmeyi kullanarak daha iyi bir performans sergilediğini, Cumming ve Hall (2002) ise bölgesel ve ulusal liglerde mücadele eden sporcular üzerinde yaptıkları çalışmada sezon sonunda ulusal ligde oynayan sporcuların bölgesel ligde oynayan sporculara göre daha fazla hayal etmeyi kullandıklarını tespit etmiştir. Araştırmacılar çoğunlukla hayal etme durumunu sportif etkinlik içerisinde uygulayan sporcuların daha yüksek beceri seviyesine sahip olduğunu bulmuşlardır. Katılımcılar derin gevşemenin ilk anlarında komutlarla imgeleme yaparak kendi hayal dünyalarında olmak istedikleri yeri yarattıklarını söylemişlerdir. Yoga ile uğraştıkça hareketleri kavrayan katılımcılar asanaları (hareketleri, duruşları) yapmanın hayal gibi olduğunu yani zamanla yapamayacaklarını düşündükleri hareketleri yapabilir hale geldiklerini belirtmişlerdir.

Eğlence; Worby (2010)'e göre yaşı, kilosu, bedensel esneklik ve sağlık durumu ne olursa olsun, her insanın yoga yapabileceğini belirtilmiştir. Herkese uygun bir yoga programı hazırlanarak hareketler bireyin gereksinimlerine göre seçilmesi gerekmektedir. Zor gibi görünse de yoga yapmak öğrendikten sonra, eğlenceli ve rahatlatıcıdır (Taşpınar, 2010). Ekici ve ark. (2009)'nın yapmış olduğu bir çalışmada, boş zaman etkinliklerinin öğrenciler üzerinde nasıl bir etki bıraktığına ilişkin olarak, öğrenciler \%22,2 oranında stresten uzaklaştıklarını, \%15,7 oranında dinlendirici bulduklarını, \%8,3 oranında eğlenceli ve heyecan verici bulduklarını belirtmişlerdir. Sit ve Lindner (2006)'ın Hong Kong'ta yaptığı çalışma sonucu eğlence, fiziksel uygunluk, arkadaşlık ve beceri gelişimini spora ve fiziksel aktiviteye katılımda göz önünde bulundurulan en önemli nedenler olarak bulmuşlardır. Salguero ve ark. (2003)'nın İspanyol yüzücülerle yaptıkları çalışmada, aktiviteye katılım motivasyonunda kızların erkeklere göre başarı ve statüden ziyade eğlencenin daha ön plana çıktığı sonucuna ulaşılmıştır. Katılımcı öğrencilerin yoğun okul müfredatı sonucunda zihinlerini boşaltıp rahatlatabilecekleri bir fiziksel aktiviteye katılarak keyifli zaman geçirdikleri ve eğlendikleri gözlemlenmiştir. Ders dışı fiziksel etkinliklerin kız öğrencilere, okulun sadece sınavların, derslerin değil aynı zamanda eğlenceli oyun ve etkinliklerin de yapıldığı, eğlenebilecekleri bir kurum olduğunun gösterilmesiyle okulu daha çok sevmelerine ortam hazırlayacağı söylenebilir.

Akademik başarl; Bir ders dışı etkinlik olarak spor, öğrencinin bir bütün olarak gelişimine katkı sağlamaktadır. Ayrıca yapılan araştırmalar, okullardaki spor etkinliklerinin akademik başarıya, okula devama, bir üst öğrenimi tercih etmeye, okulu bırakmaları önlemeye, okul kültürünün gelişimine, liderliğin gelişimine olumlu etkide bulunduğunu göstermektedir (Köse, 2013). Mamak ve Pepe (2002), Ekici ve ark. (2009)'nın yapmış oldukları çalışmalarda ders dışı etkinliklerin derslerdeki başarıyı artırdığı tespit edilmiştir. Ayrıca yapılan bir çok fiziksel uygunluk çalışması fiziksel olarak daha aktif olan gençlerin optimal yani en uygun fiziksel büyüme ve gelişme gösterdiklerini, duygusal olarak daha dengeli olduklarını ve akademik başarılarının daha iyi olduğunu göstermektedir (Haskell ve ark, 1985). Yoga ile rahatlamış, gevşemiş bir kişi, yapmak, tamamlamak zorunda oluğu bir işi, kendini daha çok işe vererek yerine getirmektedir ve performans düzeyi yükselmektedir (Ercan, 2005). Kauts ve Sharma (2009)'nın araştırmasında uygulanan yoganın deneklerde var olan stresi azaltarak akademik başarılarını arttırdığı sonucuna ulaşılmışıı. Kız öğrencilerin yoga etkinliklerine katılarak fiziksel ve zihinsel olarak gelişimleri sonucunda kendilerine güvenleri artarak nefes egzersizleri ile dinlemeye daha iyi odaklandıklarını ve derslere olan konsantrasyonlarının eskiye oranla olumlu gelişme kat ettiğini söylemişlerdir. Bu durumun akademik başarılarına da katkı sağladığını belirtmişlerdir.

Sonuç olarak; DDE çalışmaları kapsamında yapılan yoga uygulamalarının, katıımcıları zihinsel ve bedensel olarak rahatlatarak üzerindeki stresi azalttığı tespit edilmiştir. Bu rahatlama bireyin yapacağı işe karşı duyduğu motivasyonu artırımasının yanı sıra, ana odaklanmasını sağlayarak konsantrasyonuna da olumlu etki oluşturmaktadır. Böylece kendinin farkına varan birey önyargılarını ortadan kaldırarak, geleceğe dair kurduğu hayalleriyle birlikte olumlu düşünceler oluşturur. Bireyin kendine ayırdığı bu zaman içerisinde yaptığı yoga uygulamaları sonucunda bedensel ve ruhsal olarak gösterdiği gelişimle sağlam bir özgüvene ve fiziksel sağlığa erişebileceği söylenebilir. 


\section{Kaynakça}

Acar, Z. (2012). Ilköğretim Öğrencilerinin Beden Eğitimi ve Ders Dışı Etkinliklere Katılım Motivasyonlarının Incelenmesi, Ankara Üniversitesi Sağılk Bilimleri Enstitüsü, Beden Eğitimi ve Spor Anabilim Dalı Yüksek Lisans Tezi, Ankara.

Acara Australion Curriculum. (2012). Assesment and Reporting Authority, Australian Curriculum Health and Physical Education: Foundation To Year 10 Draft For Consultation, http://consultation.australiancurriculum.edu.au adresinden 05.02.2015 tarihinde erişildi.

Ağaoğlu, Y. S. (2003). Türkiye'deki Üniversitelerin Rekreasyon Programlarının Geliştirilmesi, Doktora Tezi, Ondokuz Mayıs Üniversitesi, Sağlık Bilimleri Enstitüsü, Samsun.

Akar V. (2015). Yaşam Vadisi Medikal Yoga Terapileri, http://www.yasamvadisi.com/antiaging ve medikal yoga-s38.html, adresinden 25.02.2015 tarihinde erişildi.

Akgül S. Göral M., Demirel M. ve Üstün Ü. D. (2012). İlköğretim Öğrencilerinin Okul iç̧i ve Okullar Arası Sportif Etkinliklere Katılma Nedenlerinin Çeşitli Değişkenler Açısından Araştırılması, Dumlupınar Üniversitesi Sosyal Bilimleri Dergisi, 32(I), 1302-1842.

Akkaya, S. (2008). Üniversite Öğrencilerinin Popüler Kültür Etkinlikleri ve Boş Zaman Alışkanlıkları, Anadolu Üniversitesi Sosyal Bilimler Enstitüsü Yüksek Lisans Tezi, Eskişehir.

Allen, J. B. (2003). Social motivation in youth sport. Journal of sport and exercise psychology, 25(4), 551-567.

Altunışık, R., Coşkun, R., Bayraktaroğlu, S., ve Yıldıım, E. (2004). Sosyal Bilimlerde Araştırma Yöntemleri. Sakarya: Sakarya Kitabevi.

Arslan, S. (2011). Serbest Zaman Kullanımı: Sıradan Serbest Zaman Etkinlikleri ve Sistemli Serbest Zaman Etkinlikleri. Erzincan Eğitim Fakültesi Dergisi, 13(2), 1-10.

Bagchi, B. K. ve Wenger, M. A. (1957). Electrophysiological correlates of some yogi exercises. Electroencephalography and Clinical Neurophysiology, 7, 132-149.

Bailey, D.A. ve Martin, D.A. (1994). Physical Activity and Skeletal Health in Adolescents. Pediatric Exercise Science, 6, 330-347.

Baş, Ü. (2000). Hatha Yoga ve Klasik Egzersiz Yaklaşımının Sağıkı Gençlerde Postür ve Fiziksel Uygunluk Üzerine Etkileri. Hacettepe Üniversitesi, Yüksek Lisans Tezi, Ankara.

Binbaşıŏlu, C. (2000). Okulda Ders Dışı Etkinlikler. MEB Öğretmen Kitapları Dizisi, İstanbul: Milli Eğitim Basımevi.

Budak, S. (2000). Psikoloji Sözlüğüu. Ankara: Bilim ve Sanat Yayınları, Birinci Basım.

Can, S. (2010). Muğla Üniversitesi Eğitim Fakültesi İlköğretim Bölümü Öğrenci Ailelerinin Boş Zaman Faaliyetlerine Katılım Biçimlerinin Belirlenmesi. Kastamonu Eğitim Dergisi, 18(3), 861 870.

Cumming, J. ve Hall, C. (2002). Athletes' use of imagery in the off-season. The Sport Psychologist, 16(2), 160-172.

Cüceloğlu, D. (1999). Insan ve Davranış, İstanbul: Remzi Kitabevi.

Çıl̆ın, Ö. (2007). Yatılı Illköğretim Bölge Okullarında Öğrenim Gören Öğrenciler ile Velilerinin Beden Eğitimi ve Ders Dışı Etkinliklere Yaklaşımları. Yayımlanmamış Yüksek Lisans Tezi, Gazi Üniversitesi, Ankara.

Datta, J. ve Broota, A. (2000). Managing obsessive compulsive disorder (OCD) with yoga and cognitive behavioural therapy. Journal of Research and Application in Clinical Psychology, 3, 41-50. 
Davidson, R. J., Kabat-Zinn, J., Schumacher, J., Rosenkranz, M., Muller, D., Santorelli, S. F. \& Sheridan, J. F. (2003). Alterations in brain and immune function produced by mindfulness meditation. Psychosomatic medicine, 65(4), 564-570.

Demirhan, G. (2006). Spor Eğitiminin Temelleri, Bağırgan Yayınevi, Ankara.

Doydu, i. (2012). Illköğretim II. Kademe Ders Dışı Futbol Çalışmasında Uygulanan Spor Eğitimi Modelinin Öğrencilerin Bilişsel, Psikomotor ve Oyun Performansı Erişi Düzeylerine Etkisi, Abant İzzet Baysal Üniversitesi, Eğitim Bilimleri Enstitüsü, Beden Eğitimi Öğretmenliği Anabilim Dalı Yüksek Lisans Tezi, Bolu.

Duman, S. (2003). Özel Eğitim Sınıflarında Uygulanan Beden Eğitimi Dersi Öğretim Programının Öğretmen Görüşleriyle Değerlendirilmesi, Selçuk Üniversitesi Sağılk Bilimleri Enstitüsü Spor Yöneticiliği Anabilim Dalı, Yüksek Lisans Tezi, Konya.

Duyan, E.C. (2008). Çalışma Yaşamında Yoga: Iş̧ Tatmini ve Stres Yönetiminde Etkileri Üzerine Bir Araştırma, Üniversitesi Sosyal Bilimler Enstitüsü, Çalışma Ekonomisi ve Endüstri illişkileri Anabilim Dalı, Yönetim ve Çalışma Psikolojisi Bilim Dalı, Yüksek Lisans Tezi, Bursa.

Ekici, S., Bayrakdar, A. ve Uğur, A. O. (2009). Ortaöğretim kurumlarındaki yöneticilerin ve öğrencilerin ders dışı etkinliklere bakış açılarının incelenmesi. Ulus/ararası Insan Bilimleri Dergisi, 6(1), 430-444.

Elo, S. ve Kyngas, H. (2008). The qualitative content analysis process. Journal of advanced nursing, 62(1), 107-115.

Ercan, O. (2005). Adolesanın Psikososyal Gelişimi. İstanbul: Adölesan Sağllğı Sempozyum Dizisi, Sayı 43.

Gökalp, H. (2007). Gençliğin Boş Zamanlarını Değerlendirmesinde Spor Faaliyetlerinin Yeri ve Önemi (Tunceli ili Örneği). Fırat Üniversitesi Sağlık Bilimleri Enstitüsü, Beden Eğitimi ve Spor Anabilim Dalı, Yüksek Lisans Tezi, Elazı̆̆.

Gregg, M. ve Hall, C. (2006). The relationship of skill level and age to the use of imagery by golfers. Journal of Applied Sport Psychology, 18(4), 363-375.

Haskell, W. L., Montoye, H. J., \& Orenstein, D. (1985). Physical activity and exercise to achieve health-related physical fitness components. Public Health Reports, 100(2), 202-212.

His, Türkiye Herkes İçin Spor Federasyonu, (2015) Resmi Web Sitesi, http://www.his.gov.tr/index.php?Sayfa=haberlisteweb\&tur=HT_02_DUYURU\&ld=172, adresinden 06.06.2015 tarihinde erişilmiştir.

Karataş, Z. (2015). Sosyal Bilimlerde Nitel Araştirma Yöntemleri. Manevi temelli sosyal hizmet araştırmaları dergisi, 1(1), 62-80.

Kabat-Zinn, J. (2003). Mindfulness-based interventions in context: past, present, and future. Clinical psychology: Science and practice, 10(2), 144-156.

Kauts, A. ve Sharma, N. (2009). Effect of yoga on academic performance in relation to stress. International journal of yoga, 2(1), 39-43.

Khalsa, S. ve Gould, J. (2012). Your Brain on Yoga (Harvard Medical School Guide), Harvard Medical School Guides, Rosetta Books, ISBN: 9780795332944.

Kılıç, S, (2009). Biyoistatistik Anabilim Dal Ölçümlerin Uyumluluğu ve Tıptaki Uygulamaları, Çukurova Üniversitesi, Sağıık Bilimleri Enstitüsü, Yüksek lisans Tezi, Adana.

Körükcü, Ö. \& Kukulu, K. (2015). Beden-Zihin-Ruh Bütünlüğünü Korumaya Yönelik Bir Program: Farkındalık Temelli Stres Azaltma Programı. Psikiyatride Güncel Yaklaşımlar, 7(1), 68-80.

Köse, E. (2004). İlköğretim öğrencilerinin ders dışı etkinlikleri tercih etme nedenleri. XIII. Ulusal Eğitim Bilimleri Kurultayı, Inönü Üniversitesi, Malatya.

Köse, E. (2013). Eğitim kurumlarında gerçekleştirilen ders dışı etkinliklerin sınıflandırılmasına yönelik bir öneri. Uluslararası Türkçe Edebiyat Kültür Eğitim Dergisi, 2(2), 336-353. 
MEB Eğitim Araştırma ve Gelişim Dairesi Başkanlığı. (2014). Okul Pansiyonlarının Etkiliğinin Değerlendirilmesi, Ankara 2005. http://Yegitek.Meb.Gov.Tr/ Tamamlanan/Okul Pansiyon Etkiligi (K\%C4\%B1z_Teknik.Pdf, adresinden 04.11.2014 tarihinde erişilmiştir.

Oken, B. S., Zajdel, D., Kishiyama, S., Flegal, K., Dehen, C., Haas, M. \& Leyva, J. (2006). Randomized, controlled, six-month trial of yoga in healthy seniors: effects on cognition and quality of life. Alternative therapies in health and medicine, 12(1), 40.

Özdemir, M. (2010). Nitel Veri Analizi: Sosyal Bilimlerde Yöntembilim Sorunsalı Üzerine Bir Çalışma. Eskişehir Osmangazi Üniversitesi Sosyal Bilimler Dergisi, 11(1), 323-343.

Rani, N. J. ve Rao, P. K. (2005). Impact of yoga training on body image and depression. Psychological Studies-University of Calicut, 50(1), 98.

Rao, K. (2000). Stress and its management. In P.Jose (Ed.), Indian Health-A Reference Documen., Kerala:Deepika Publishers.

Salguero, A., Gonzalez-Boto, R., Tuero, C., \& Marquez, S. (2003). Identification of dropout reasons in young competitive swimmers. Journal of Sports Medicine and Physical Fitness, 43(4), 530.

Saraswati, S. J. (2001). Günlük Yaşamda Yoga, Tantra ve Meditasyon. İstanbul: Okyanus Yayıncılık.

Singh A. ve Mishra, G. (2015). Therapeutic Effectiveness of Yoga for Psychological Health and Wellbeing, JOY: The Journal of Yoga, http://www.journalofyoga.org/therapeuticyoga.pdf, adresinden 24.06.2015 tarihinde erişilmiştir.

Schultz, L. H., Uyterhoeven, S. ve Khalsa, S. B. S. (2011). Evalution of Yoga, Program for Back Pain, Yoga and Physical Therapy, 1(2), 103.

Simard, A. A. ve Henry, M. (2009). Impact of a short yoga intervention on medical students' health: a pilot study. Medical teacher, 31(10), 950-952.

Sit, C. H. ve Lindner, K. J. (2006). Situational state balances and participation motivation in youth sport: A reversal theory perspective. British Journal of Educational Psychology, 76(2), 369-384.

Stueck, M. ve Gloeckner, N. (2005). Yoga for children in the mirror of the science: Working spectrum and practice fields of the training of relaxation with elements of yoga for children. Early child development and care, 175(4), 371-377.

Sağlık Bakanlığı Türkiye Halk Sağlığı Kurumu (2014). Türkiye Fiziksel Aktivite Rehberi, Ankara, Http://Beslenme.Gov.Tr/Content/Files/Basin

Materyal/Fiziksel Aktivite Rehberi/Farehberi Tr.Pdf adresinden $\quad 14.06 .2015$ tarihinde erişilmiştir.

Taşpınar B, (2010). Hatha Yoga ve Dirençli Egzersizlerin Erişkinlerde Psiko-Sosyal Faktörlere Etkilerinin Karşılaştırılması, Pamukkale Üniversitesi Yayımlanmamış Doktora Tezi, Denizli.

Tezcan, M. (1993). Bos Zamanlar Sosyolojisi. Eskişehir, A.Ü. Egitim Fak. Yayınları.

Tran, M. D., Holly, R. G., Lashbrook, J. ve Amsterdam, E. A. (2001). Effects of Hatha yoga practice on the health-related aspects of physical fitness. Preventive cardiology, 4(4), 165-170.

Güven Ülger, Ö., Atay, S. ve Arslan, E. (2007). Sağlıklı kadınlarda Hatha Yoganın esneklik ve denge üzerine etkileri. Fizyoter Rehabil, 18, 72-78.

Worby, C. (2010). Her Yönüyle Yoga, Ankara, Arkadaş Yayınevi.

World Health Organization, (2015) http://Www.Who.Int/Mediacentre/Factsheets/ Fs311/En/ adresinden 04.07.2015 tarihinde erişilmiştir.

Yaman, E. (2010). Psikoşiddete (mobbinge) maruz kalan öğretim elemanlarının örgüt kültürüne ve iklimine ilişkin algıları. Kuram Uygulamada Eğitim Bilimleri Dergisi, 10(1), 449-578.

Yarcheski, A., Mahon, N. E. \& Yarcheski, T. J. (1997). Alternate models of positive health practices in adolescents. Nursing research, 46(2), 85-92.

Yıldırım, A. ve Şimşek, H. (2013). Sosyal Bilimlerde Nitel Araştırma Yöntemleri (9. Baskı). Ankara: Seçkin Yayınevi. 


\section{Extended Summary}

\section{Introduction}

In the literature review it is seen that yoga activities lead to improve physical strength, resilience, concentration, anger management, well being, quality of life, and reduce stress.

\section{Purpose}

The main purpose of the study is to reach acquisitions as avoiding sedentary life by benefiting leisure time and as sanction to health disorders like obesity by yoga activities which thought to be implemented as extracurricular training of female students who stay school pension. With this study, it is aimed to make scientific determination about providing concentration and focusing; additionally to improve academic success, to make them healthier individuals, to gain selfconfidence and self awareness and to make them feel happy and to offer a suggestion that providing acquisition which gained by yoga activities to take place on the Ministry of Education of Extracurricular training curriculum.

\section{Method}

It is benefited from observation, interviewing, and analyze of documents as diary on qualitative research methods in this study. 41 school going female students of 14-18 years are selected for the study. Researcher stands as an observer and implementer in Golkoy Anatolian Teacher High School. Gained data is prosed in the computer environment. Then they are coded via Nvivo 10 for Windows programme. Common theme of coded data is classified by 2 experts.

\section{Findings}

It is reached demographic featured knowledge. Data which are development of awareness, physiological and psychological acquisitions, implementation of extracurricular activity; in the analyze of triangulation method offers under the main theme and reach sub themes.

\section{Discussion \& Conclusion}

It is given results concerning demographic data. It is reached two main common subjects for each as a result of gained data analysis by triangulation method. These are acquisition of yoga as extracurricular activities and offer of extracurricular activities. Besides, as extracurricular training is reached three common subjects. Firstly, psychological acquisition based on focusing, concentration, relaxation, self-confidence, motivation, stress, happines and thinking positively, secondly concerning physiological acquisition it is reached common theme as physical health and development of motor ability third and the last common theme in this research is self-awareness and prejudice by concerning awareness. Extracurricular training offers three common points such as saving time of herself/himself, curiosity, detection, imagination, having fun and academic success. To sum up it is stated that yoga practises which is done in the frame of extracurricular training studies, reduce stress by relaxing applicants mentally and physically. This relaxation has positive impact on concentration by providing focus as well as increasing motivation to what people do. Thus, individuals who has self-awareness remove prejudice and start to think positively for the future. As a consequence of yoga activities applicants are improved mentally, physically. It makes individual to have self-confidence and physical health. 